\title{
Evaluation of current and projected Antarctic precipitation in CMIP5 models
}

\author{
Cyril Palerme $^{1,2} \cdot$ Christophe Genthon $^{1,2} \cdot$ Chantal Claud $^{3} \cdot$ Jennifer E. Kay ${ }^{4}$. \\ Norman B. Wood ${ }^{5}$ Tristan L'Ecuyer ${ }^{6}$
}

Received: 6 July 2015 / Accepted: 5 March 2016 / Published online: 30 March 2016

(C) The Author(s) 2016. This article is published with open access at Springerlink.com

\begin{abstract}
On average, the models in the Fifth Climate Model Intercomparison Project archive predict an increase in Antarctic precipitation from 5.5 to $24.5 \%$ between 1986-2005 and 2080-2099, depending on greenhouse gas emissions scenarios. This translates into a moderation of future sea level rise ranging from -19 to $-71 \mathrm{~mm}$ between 2006 and 2099. However, comparison with CloudSat and ERA-Interim data show that almost all the models overestimate current Antarctic precipitation, some by more than $100 \%$. If only the models that agree with CloudSat data within $20 \%$ of error are considered, larger precipitation changes (from 7.4 to $29.3 \%$ ) and impact on sea level (from -25 to $-85 \mathrm{~mm}$ ) are predicted. A common practice of averaging all models to evaluate climate projections thus leads to a significant underestimation of the contribution of Antarctic precipitation to future sea level. Models simulate, on average, a $7.4 \% /{ }^{\circ} \mathrm{C}$ precipitation change with surface temperature warming. The models in better agreement with CloudSat observations for Antarctic snowfall predict, on average, larger temperature and Antarctic sea ice cover
\end{abstract}

Cyril Palerme

cyrilpalerme@gmail.com

CNRS, LGGE, 38041 Grenoble, France

2 Université Grenoble Alpes, LGGE, 38041 Grenoble, France

3 LMD/IPSL, CNRS and Ecole Polytechnique, Université Paris-Saclay, Palaiseau, France

4 Cooperative Institute for Research in Environmental Sciences, Department of Atmospheric and Oceanic Sciences, University of Colorado at Boulder, Boulder, CO, USA

5 Cooperative Institute for Meteorological Satellite Studies, University of Wisconsin-Madison, Madison, WI, USA

6 Department of Atmospheric and Oceanic Sciences, University of Wisconsin-Madison, Madison, WI, USA changes, which could explain the larger changes in Antarctic precipitation simulated by these models. The agreement between the models, CloudSat data and ERA-Interim is generally less in the interior of Antarctica than at the peripheries, but the interior is also where climate change will induce the smallest absolute change in precipitation. About three-quarters of the impact on sea level will result from precipitation change over the half most peripheral and lowest elevation part of the surface of Antarctica.

Keywords Antarctica - Precipitation - CloudSat . CMIP5 - Sea level

\section{Introduction}

Predicting the evolution of the Antarctic ice sheet is a major challenge with relevance to sea level rise. While satellite observations indicate an increasing ice loss in West Antarctica due to ongoing outlet glacier acceleration (Rignot et al. 2008; Velicogna 2009; Shepherd et al. 2012), Antarctic snow accumulation is expected to increase in a warming climate (Gregory and Huybrechts 2006; Frieler et al. 2015), moderating the future contribution of the Antarctic ice sheet to sea level rise. However, no clear trend in snow accumulation has been extracted for the last decades from observations and reanalysis data for the whole Antarctic continent (Monaghan et al. 2006; Frezzotti et al. 2013).

Climate models participating in the Coupled Model Intercomparison Project Phase 5 (CMIP5) consistently predict Antarctic precipitation to increase in a warming climate (Church et al. 2013). Due to this change in precipitation, snow accumulation (the sum of precipitation, sublimation/evaporation, meltwater run-off, and blowing snow) should also increase in Antarctica (Church et al. 2013). 
However, models differ widely on their simulations of the current precipitation rate in Antarctica. There is, therefore, a need to evaluate climate models with precipitation observations, and to understand the processes controlling Antarctic precipitation.

Antarctic snow accumulation has been estimated using in-situ measurements and passive microwave radiometers (Vaughan et al. 1999; Arthern et al. 2006), although uncertainties remain concerning the use of inaccurate insitu observations (Magand et al. 2007), and the interpolation based on microwave surface emission is affected by melt over coastal areas during the summer (Magand et al. 2008). In contrast, precipitation has been more complicated to assess due to the inherent challenges associated with measuring precipitation in Antarctica. In coastal areas, it is difficult to separate precipitation and blowing snow caused by strong katabatic winds. In the interior of the ice sheet, where precipitation rates are very small (Bromwich et al. 2004; Palerme et al. 2014), the sensors must be able to detect very light precipitation. In addition, low temperatures and hoarfrost negatively impact instruments that are not designed for harsh environments.

Moreover, no precipitation climatology has resulted so far from passive microwave remote sensing since it is difficult to distinguish the signals from falling snow and snow on the ground. An approach has been developed to detect snowfall occurrence using changes in surface emissivity (Bindschadler et al. 2005), but the method was not quantitative.

Quantitative Antarctic precipitation observations have recently become available with the data provided by the cloud profiling radar (CPR) onboard the CloudSat satellite (Stephens et al. 2008; Liu 2008). Palerme et al. (2014) used two new CloudSat products to generate the first modelindependent and multi-year climatology of Antarctic precipitation north of $82^{\circ} \mathrm{S}$. In this study, the ability of CMIP5 climate models to reproduce present-day Antarctic snowfall is assessed against this new satellite climatology. After this model assessment, an intercomparison and analysis of CMIP5 model projections for the twenty-first century is presented. It is common to attribute a higher level of confidence in the projections from the models that most closely reproduce the current climate, so projections from the subset of models that most closely reproduce current Antarctic snowfall observed with CloudSat are also highlighted in this section. The sensitivities of Antarctic precipitation to near-surface air temperature and sea ice area changes are also investigated.

\section{Data and methods}

The CloudSat product 2C-SNOW-PROFILE (Wood et al. 2013) that provides instantaneous estimates of snowfall since August 2006 was aggregated to a $1^{\circ}$ (latitude) $\times 2$ (longitude) grid between $63^{\circ} \mathrm{S}$ and $82^{\circ} \mathrm{S}$ as described by Palerme et al. (2014). Due to battery problems, CloudSat has not provided any data during the night since April 2011, thus the period 2007-2010 is adopted in this study to take into account the four complete years available from the CloudSat 2C-SNOW-PROFILE product. The uncertainty on this climatology can not be easily estimated, but good agreement has been found between this climatology and ERA Interim reanalysis, which is encouraging for the reliability of both datasets (Palerme et al. 2014). However, precipitation events occurring below $1200 \mathrm{~m}$ above the surface are missed with the CloudSat 2C-SNOW-PROFILE algorithm due to ground clutter contamination (Wood et al. 2013).

ERA Interim reanalysis is used as a second indicator for model evaluation. ERA Interim is a global comprehensive atmospheric reanalysis produced by the European Centre for Medium Range Weather Forecasts (ECMWF) (Simmons et al. 2006). It covers the period from 1979 to present at a 6-hourly resolution, and with a spatial resolution of about $0.75^{\circ} \times 0.75^{\circ}$. The 6 and 12-h forecasts of precipitation are used here. Data from surface observations and radiosondes, commercial aircraft observations, and satellite measurements are assimilated in the numerical model to improve and constrain the forecasts (Dee et al. 2011). CloudSat observations are not incorporated in the ERA interim reanalysis. Direct precipitation observations are not assimilated into the model, but precipitation is modified in the analysis through the four-dimensional variational assimilation of other variables such as temperature and humidity (Dee et al. 2011). It has been shown that the snow accumulation (defined as precipitation minus evaporation) simulated by ERA Interim reanalysis is close to airborne radar observations over Thwaites Glacier in West Antarctica (Medley et al. 2013). Moreover, it has been suggested that ERA Interim likely offers the most realistic depiction of precipitation changes in Antarctica among various reanalysis datasets (Bromwich et al. 2011). Nevertheless, similar parameterizations could be used in ERA Interim reanalysis and the CMIP5 models for simulating precipitation, which could induce similar bias in the different datasets.

The Historical scenario, in which the coupled climate models are forced by observed atmospheric composition changes from the middle of the nineteenth century to the early twenty-first century (Taylor et al. 2012), has been used for current climate evaluation. Simulations of Antarctic snowfall in the Historical scenario have been compared to simulations from the Atmospheric Model Intercomparison Project (AMIP) experiment to investigate the influence of sea surface conditions on Antarctic precipitation. In the AMIP experiment (Gates 1992), the atmospheric models are constrained by realistic sea surface temperature and sea 
Fig. 1 Scatter plot comparing the mean snowfall rate in CloudSat observations during the period 2007-2010 and in ERA Interim reanalysis during the period 1986-2005 at each grid point. 9 of the 1716 values, characterized by very high snowfall rates in CloudSat observations (higher than $1000 \mathrm{~mm} /$ year) are not shown on this figure for more clarity (see main text for details). The 1:1 line (blue line) and the linear regression line (red line) are also shown on this figure

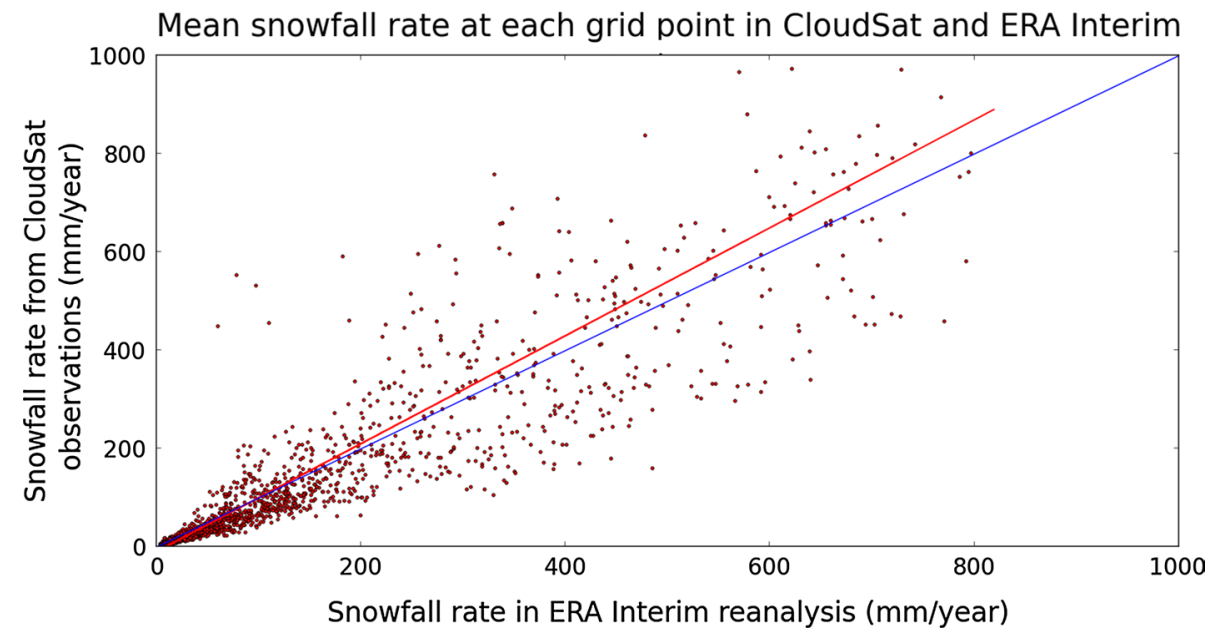

ice from 1979 to near present (2008 for most of the CMIP5 models). Because the atmospheric models are not subject to the ocean-atmosphere feedbacks, the AMIP experiment is expected to be the most reliable experiment for current precipitation simulations.

For current climate evaluation, the period 1986-2005 has been adopted for all datasets, except for CloudSat observations for which the period 2007-2010 has been used. The spatial pattern of the snowfall rate in ERA Interim reanalysis during the period 1986-2005 is similar to the spatial pattern of the snowfall rate from CloudSat observations during the period 2007-2010 (Fig. 1 and top row in Fig. 2). Figure 1 shows a scatter plot comparing the mean snowfall rate in CloudSat observations during the period 2007-2010 and in ERA Interim reanalysis during the period 1986-2005. In Fig. 1, 9 of the 1716 values, characterized by very high snowfall rates in CloudSat observations (more than $1000 \mathrm{~mm} /$ year), are not shown for more clarity. All of these values are located in mountainous areas: in the Peninsula, the Vinson massif $\left(78^{\circ} \mathrm{S}, 85^{\circ} \mathrm{W}\right)$, and the Prince Charles Mountains (around $72^{\circ} \mathrm{S}, 65^{\circ} \mathrm{E}$ ). The Pearson correlation coefficient between CloudSat observations and ERA Interim reanalysis is 0.59 if all the values are taken into account, but is really better $(0.91)$ without these nine values. There are issues concerning both datasets over mountainous areas. In CloudSat observations, the ground clutter is likely stronger over mountainous areas than over flat terrain, and may induce a spuriously high snowfall rate, while orographic precipitation may not be well represented in ERA Interim due to a too coarse spatial resolution.

In ERA Interim, the mean snowfall rate on the Antarctic continent north of $82^{\circ} \mathrm{S}$ is similar during the period 1986-2005 (165 mm/year) and during the period covered by CloudSat observations ( $165 \mathrm{~mm} /$ year between 2007 and 2010). Although the interannual variability of Antarctic snowfall could be very high at regional scales, it is relatively weak at the continent scale. The standard deviation of the mean annual snowfall rate, north of $82^{\circ} \mathrm{S}$, is $5.7 \mathrm{~mm} /$ year in ERA Interim and $8.7 \mathrm{~mm} /$ year in CloudSat between 2007 and 2010. Between 1986 and 2005, this standard deviation is $7.9 \mathrm{~mm} /$ year in ERA Interim. Finally, the spatial pattern of the snowfall rate in ERA Interim reanalysis is similar during the periods 1986-2005 and 2007-2010 (top row in Fig. 2). Therefore, it is assumed that the period 2007-2010 covered by CloudSat observations is representative of the period 1986-2005.

For current climate evaluation only snowfall is considered in the models for direct comparison with CloudSat observations. However, liquid precipitation is very infrequent in Antarctica (Bengtsson et al. 2011; Palerme et al. 2014), and it is expected that the snowfall rate is very close to the precipitation rate. Furthermore, due to the narrow orbit track of CloudSat $(1.3 \mathrm{~km})$, which only operates at nadir, the surface directly covered by CloudSat observations is only a fraction of the total surface of the ice sheet (Palerme et al. 2014). Nevertherless, the CloudSat spatiotemporal sampling is better at high latitudes, and is likely sufficient to be representative of a climatology in Antarctica if several years of observations are taken into account (Palerme et al. 2014).

For precipitation projections, we used the four experiments Representative Concentration Pathway (Moss et al. 2010): RCP2.6, RCP4.5, RCP6.0, and RCP8.5. These scenarios are labeled according to the approximate values of the global radiative forcing in 2100 (in $\mathrm{W} / \mathrm{m}^{2}$ ). For all the variables used in this study, the mean value of the variable is assessed in the last 20 years of the simulations in the Historical scenario (1986-2005), and in the last 20 years of the century in the RCP scenarios (2080-2099). Thus, the trends assessed for the twenty-first century represent the difference between the periods 1986-2005 and 2080-2099.

The list of the models used in this study is shown in Table 1. Several simulations are provided for some models in order to characterize their own internal variability and 

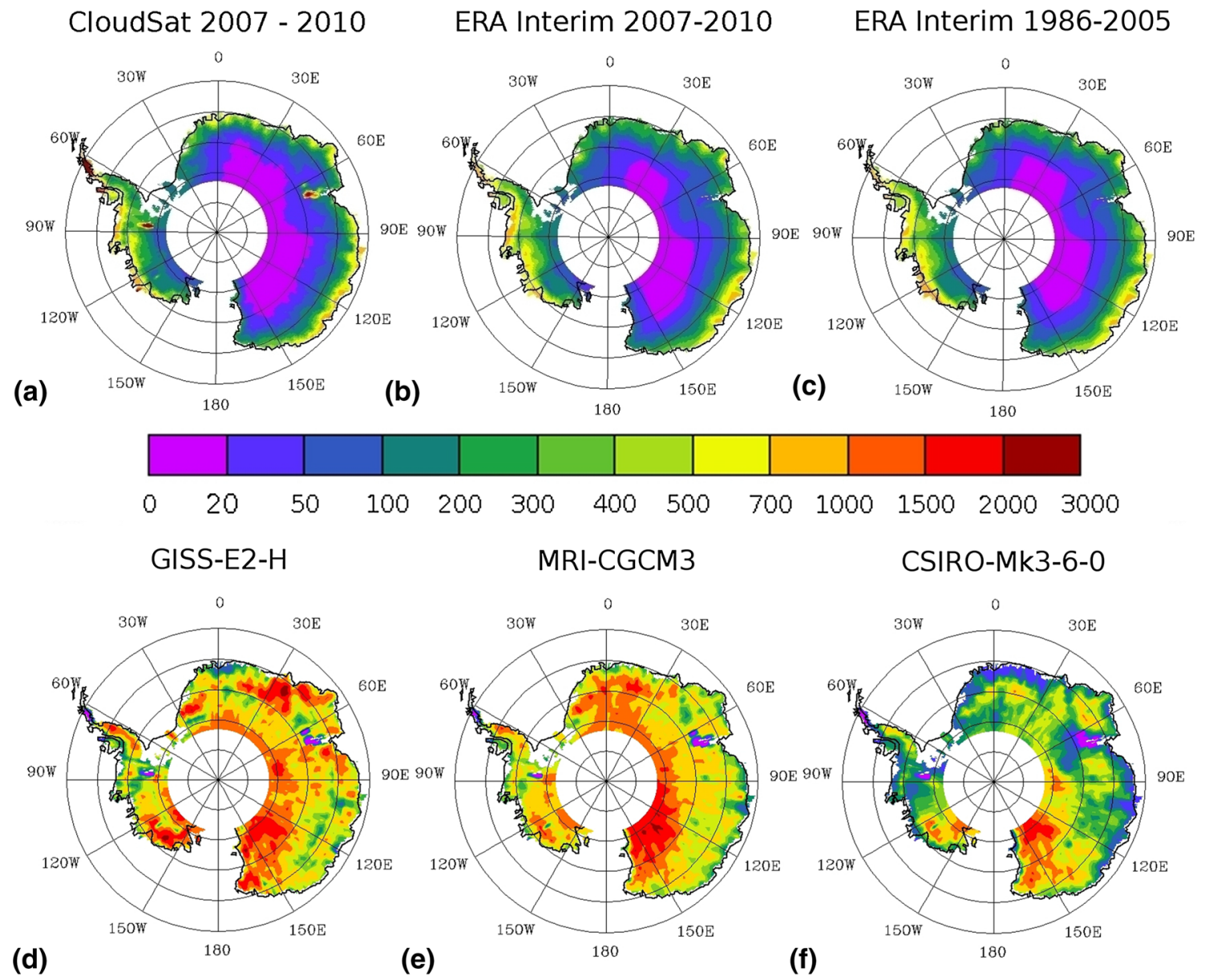

(e)

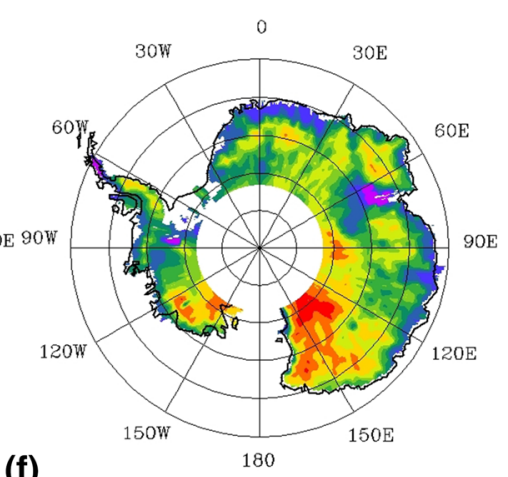

$\operatorname{CCSM} 4$
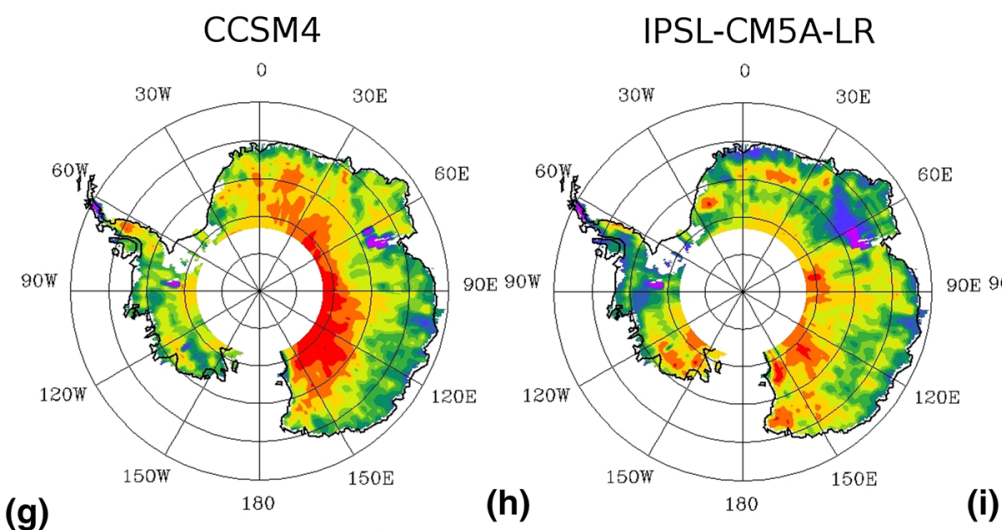

\section{ALTITUDE (2250m)}

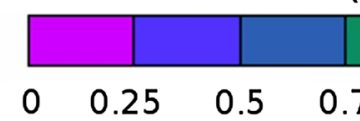

(h)

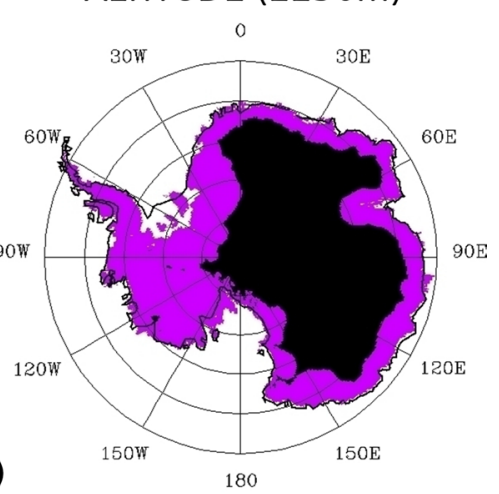

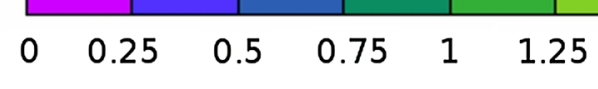

Fig. 2 Mean annual snowfall rate ( $\mathrm{mm}$ water equivalent / year) north of $82^{\circ} \mathrm{S}$ observed with CloudSat during the period 2007-2010 (a), and simulated by ERA Interim during the periods 2007-2010 (b) and 1986-2005 (c). Ratio of the snowfall rate simulated by five CMIP5

sensitivity to initial conditions. When there were several simulations for a same model, the mean value of the simulations was taken into account for comparing the different models. models during the period 1986-2005 in the Historical scenario over the snowfall rate observed with CloudSat $(\mathbf{d}, \mathbf{e}, \mathbf{f}, \mathbf{g}, \mathbf{h})$. The regions with surface elevation higher than $2250 \mathrm{~m}$ (black) and lower than $2250 \mathrm{~m}$ (purple) are shown on the last map (i)

Two regions have been analyzed separately in this study (except for the mean annual snowfall rate which has been studied in six different areas): the periphery of the ice sheet which corresponds to the part of the continent with surface 
Table 1 Models used for the different scenarios

\begin{tabular}{|c|c|c|c|c|}
\hline Historical & $\mathrm{RCP} 2.6$ & $\mathrm{RCP} 4.5$ & RCP6.0 & RCP8.5 \\
\hline ACCESS1-0 & Bcc-csm1-1-m & ACCESS1-0 & Bcc-csm1-1-m & ACCESS1-0 \\
\hline ACCESS1-3 & Bcc-csm1-1 & ACCESS1-3 & Bcc-csm1-1 & ACCESS1-3 \\
\hline Bcc-csm1-1-m & $B N U-E S M$ & Bcc-csm1-1-m & CCSM4 & Bcc-csm1-1-m \\
\hline Bcc-csm1-1 & CanESM2 & Bcc-csm1-1 & CESM1-CAM5 & Bcc-csm1-1 \\
\hline$B N U-E S M$ & CCSM4 & $B N U-E S M$ & CSIRO-Mk3-6-O & $B N U-E S M$ \\
\hline CanESM2 & CESM1-CAM5 & CanESM2 & $F I O-E S M$ & CanESM2 \\
\hline CCSM4 & $C E S M 1-W A C C M$ & CCSM4 & GFDL-ESM2G & CCSM4 \\
\hline CESM1-BGC & CNRM-CM5 & CESM1-BGC & GFDL-ESM2M & CESM1-BGC \\
\hline CESM1-CAM5 & CSIRO-Mk3-6-0 & CESM1-CAM5 & GISS-E2H & CESM1-CAM5 \\
\hline$C E S M 1-W A C C M$ & EC-EARTH & CESM1-WACCM & GISS-E2-R & CESM1-WACCM \\
\hline CMCC-CESM & FGOALS-g2 & CMCC-CM & HadGEM2-AO & CMCC-CESM \\
\hline CMCC-CM & $F I O-E S M$ & CMCC-CMS & HadGEM2-ES & CMCC-CM \\
\hline CMCC-CMS & GFDL-CM3 & CNRM-CM5 & $I P S L-C M 5 A-L R$ & CMCC-CMS \\
\hline CNRM-CM5 & GFDL-ESM2G & CSIRO-Mk3-6-O & IPSL-CM5A-MR & CNRM-CM5 \\
\hline CSIRO-Mk3-6-0 & GFDL-ESM2M & EC-EARTH & MIROC5 & CSIRO-Mk3-6-O \\
\hline EC-EARTH & GISS-E2-H & FGOALS-g2 & MIROC-ESM-CHEM & EC-EARTH \\
\hline FGOALS-g2 & GISS-E2-R & $F I O-E S M$ & MIROC-ESM & FGOALS-g2 \\
\hline$F I O-E S M$ & HadGEM2-AO & GFDL-CM3 & MRI-CGCM3 & FIO-ESM \\
\hline GFDL-CM3 & HadGEM2-ES & GFDL-ESM2G & NorESM1-ME & GFDL-CM3 \\
\hline GFDL-ESM2G & $I P S L-C M 5 A-L R$ & GFDL-ESM2M & NorESM1-M & GFDL-ESM2G \\
\hline GFDL-ESM2M & IPSL-CM5A-MR & GISS-E2-H-CC & & GFDL-ESM2M \\
\hline GISS-E2-H-CC & MIROC5 & GISS-E2-H & & GISS-E2-H \\
\hline GISS-E2-H & MIROC-ESM-CHEM & GISS-E2-R-CC & & GISS-E2-R \\
\hline GISS-E2-R-CC & MIROC-ESM & GISS-E2-R & & HadGEM2-AO \\
\hline GISS-E2-R & MPI-ESM-LR & HadGEM2-AO & & HadGEM2-CC \\
\hline HadGEM2-AO & MPI-ESM-MR & HadGEM2-CC & & HadGEM2-ES \\
\hline HadGEM2-CC & MRI-CGCM3 & HadGEM2-ES & & Inmcm4 \\
\hline HadGEM2-ES & NorESM1-ME & Inmcm4 & & $I P S L-C M 5 A-L R$ \\
\hline inmem 4 & NorESM1-M & $I P S L-C M 5 A-L R$ & & IPSL-CM5A-MR \\
\hline$I P S L-C M 5 A-L R$ & & IPSL-CM5A-MR & & IPSL-CM5B-LR \\
\hline IPSL-CM5A-MR & & IPSL-CM5B-LR & & MIROC5 \\
\hline IPSL-CM5B-LR & & MIROC5 & & MIROC-ESM-CHEM \\
\hline MIROC5 & & MIROC-ESM-CHEM & & MIROC-ESM \\
\hline MIROC-ESM-CHEM & & MIROC-ESM & & MPI-ESM-LR \\
\hline MIROC-ESM & & MPI-ESM-LR & & MPI-ESM-MR \\
\hline MPI-ESM-LR & & MPI-ESM-MR & & MRI-CGCM3 \\
\hline MPI-ESM-MR & & MRI-CGCM3 & & NorESM1-ME \\
\hline MRI-CGCM3 & & NorESM1-ME & & NorESM1-M \\
\hline NorESM1-ME & & NorESM1-M & & \\
\hline NorESM1-M & & & & \\
\hline
\end{tabular}

The models written in italic are the models which simulate a snowfall rate during the period 1986-2005 in the Historical scenario close to the CloudSat snowfall rate $( \pm 20 \%)$ on the Antarctic continent north of $82^{\circ} \mathrm{S}$

elevation below $2250 \mathrm{~m}$, and the interior of the ice sheet with surface elevation over $2250 \mathrm{~m}$. Each region constitutes $50 \%$ of the total surface of the Antarctic ice sheet (areas with an altitude higher than $2250 \mathrm{~m}$ represent $71 \%$ of the surface of East Antarctica, and $12 \%$ of the surface of West
Antarctica). These two regions are characterized by different precipitation regimes. Most of the precipitation falls on the peripheral areas of the ice sheet, and it is where the models predict the largest absolute increase during the twenty-first century (Genthon et al. 2009). Precipitation in 
these regions is mainly influenced by synoptic scale features such as cyclones and fronts (Bromwich 1988). In the interior of the ice sheet, precipitation is less influenced by the southern ocean, and very light precipitation occurs due to very low temperatures. Moreover, a potentially significant fraction of the precipitation in the interior of the ice sheet falls in the form of "diamond dust" (ice crystals) under clear sky conditions (Bromwich 1988; Fujita and Abe 2006).

\section{Evaluation of current climate simulations}

\subsection{Mean annual snowfall rate}

Figure 2 shows the ratio of the snowfall rate simulated by 5 CMIP5 models over the snowfall rate observed with CloudSat (north of $82^{\circ} \mathrm{S}$ ). These 5 CMIP5 models are representative of the range of models in the Historical scenario (Table 1). Among all the models used for the Historical scenario, the model with the lowest mean snowfall rate on the Antarctic continent north of $82^{\circ} \mathrm{S}$ during the period 1986-2005 is CSIRO-Mk3-6-0, and the model with the highest mean snowfall rate is GISSE2-H. There are large differences in the snowfall rates simulated by these models. Overall, the models reproduce a snowfall rate closer to the observations from CloudSat and ERA Interim reanalysis over the coastal areas than over the interior of the ice sheet, where they tend to simulate higher snowfall rates than CloudSat or ERA Interim reanalysis.
Figure 3 shows the mean snowfall rate assessed with CloudSat during the period 2007-2010, and the snowfall rates simulated by ERA Interim and the CMIP5 models (Historical scenario) during the period 1986-2005. Over the Antarctic continent north of $82^{\circ} \mathrm{S}$, only two models (CSIRO-Mk3-6-0 and FIO-ESM) produce a snowfall rate lower than those observed by CloudSat and simulated by ERA Interim. The snowfall rate in the CMIP5 models ranges from 158 to $354 \mathrm{~mm} /$ year, compared to $165 \mathrm{~mm} /$ year for ERA Interim, and $172 \mathrm{~mm} /$ year for CloudSat. The mean snowfall rate from all the CMIP5 models over the Antarctic continent north of $82^{\circ} \mathrm{S}$ is $224 \mathrm{~mm} /$ year. 13 of the 40 models analyzed simulate snowfall rates within $\pm 20 \%$ of CloudSat. These models are written in italic in Table 1.

Over the marginal regions of the Antarctic ice sheet (surface elevation $<2250 \mathrm{~m}$ ), the snowfall rate in the CMIP5 models ranges from 254 to $611 \mathrm{~mm} /$ year, compared to $306 \mathrm{~mm} /$ year for CloudSat, and $279 \mathrm{~mm} /$ year in ERA Interim reanalysis. The mean snowfall rate from all the CMIP5 models is $363 \mathrm{~mm} /$ year over this part of the ice sheet, $19 \%$ larger than observed by CloudSat. In this region, 6 of the 40 models analyzed produce a snowfall rate lower than the snowfall rate observed with CloudSat, but only three models produce a snowfall rate lower than the snowfall rate simulated by ERA Interim.

In the interior of the ice sheet north of $82^{\circ} \mathrm{S}$, the snowfall rate varies by a factor of two between the CMIP5 models ranging from 50 to $110 \mathrm{~mm} / \mathrm{year}$. Over this region, the mean snowfall rate from all the CMIP5 models is $74 \mathrm{~mm} /$ year, compared to $46 \mathrm{~mm} /$ year from ERA Interim and $36 \mathrm{~mm} /$ year from CloudSat. However, it is likely that

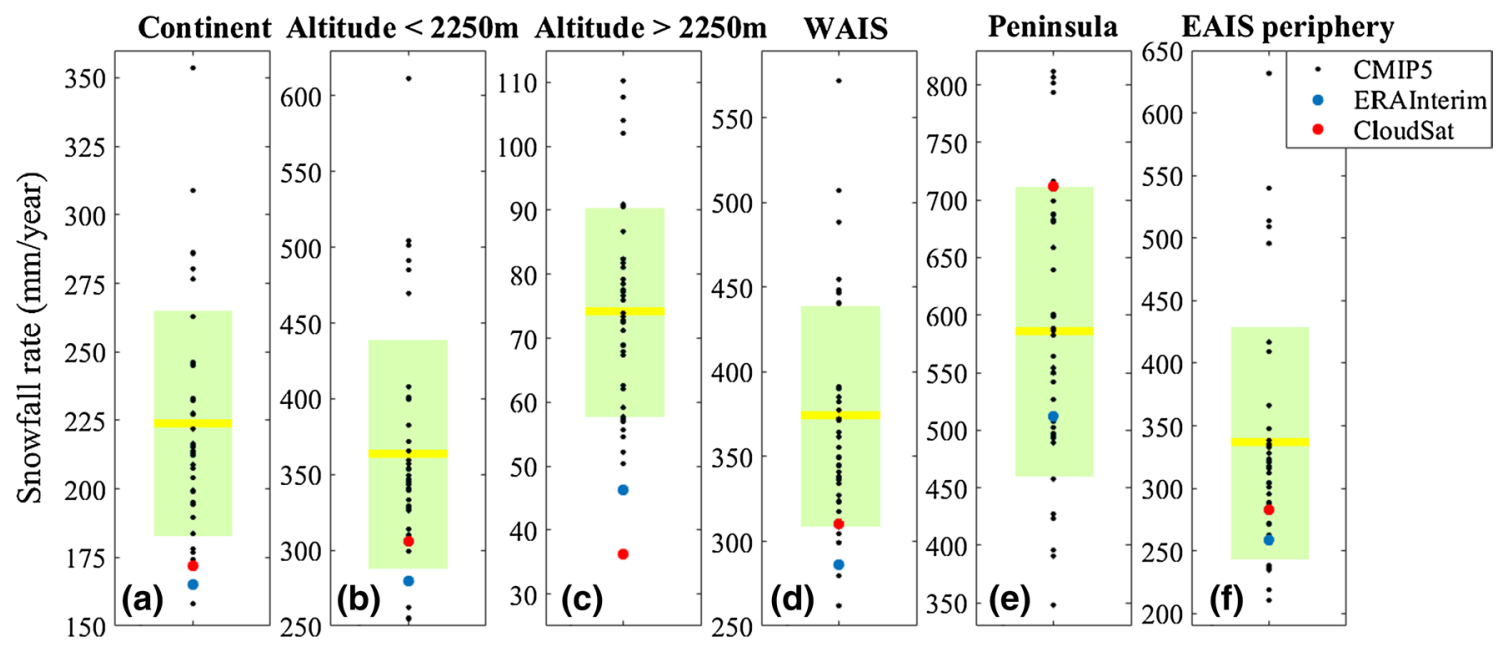

Fig. 3 Mean annual snowfall rate (mm water equivalent / year) during the period 1986-2005 for the CMIP5 models and ERA Interim, and during the period 2007-2010 for CloudSat. a Antarctic continent (north of $82^{\circ} \mathrm{S}$ ). b Peripheral regions of the ice sheet with surface elevation lower than $2250 \mathrm{~m}$ (north of $82^{\circ} \mathrm{S}$ ). c High Antarctic plateau with surface elevation higher than $2250 \mathrm{~m}$ (north of $82^{\circ} \mathrm{S}$ ). d West Antarctic ice sheet (north of $82^{\circ} \mathrm{S}$ ). e Peninsula. f Peripheral areas of the East Antarctic ice sheet with surface elevation lower than $2250 \mathrm{~m}$ (north of $82^{\circ} \mathrm{S}$ ). Red dots CloudSat, blue dots ERA Interim, and black dots CMIP5 climate models (Historical scenario). The yellow bar shows the mean snowfall rate for all the CMIP5 models, and the green rectangle shows the standard deviation 
CloudSat observations underestimate the snowfall rate in the Antarctic interior. The CloudSat algorithm used in this study is not able to detect precipitation below $1200 \mathrm{~m}$ above the surface due to ground clutter (Wood et al. 2013), and the relative contribution of shallow precipitation in the interior of the ice sheet is probably more important than on the peripheral areas. Therefore, it is likely that CloudSat observations are more reliable on the peripheral regions than in the interior of the ice sheet (Palerme et al. 2014).

Over the West Antarctic ice sheet (WAIS), the snowfall rate in the CMIP5 models ranges from 262 to $572 \mathrm{~mm} /$ year, compared to $310 \mathrm{~mm} / \mathrm{year}$ in CloudSat observations and $286 \mathrm{~mm} /$ year in ERA Interim reanalysis. The mean snowfall rate from the CMIP5 models is $374 \mathrm{~mm} /$ year over West Antarctica, $21 \%$ larger than observed by CloudSat.

CloudSat observations and ERA Interim reanalysis disagree for the mean snowfall rate over the Antarctic Peninsula $(711 \mathrm{~mm} / \mathrm{year}$ in CloudSat and $512 \mathrm{~mm} / \mathrm{year}$ in ERA Interim). The ground clutter in CloudSat observations is likely stronger over mountainous areas like the Peninsula, which may induce a spuriously high snowfall rate, whereas orographic precipitation may not be well represented in ERA Interim reanalysis due to its spatial resolution of about $80 \mathrm{~km}$ (Dee et al. 2011). The highest standard deviation for the snowfall rate in the CMIP5 models is observed over the Antarctic Peninsula with a value of $125 \mathrm{~mm} /$ year. Furthermore, the Antarctic Peninsula is the only region in which the CloudSat snowfall rate $(711 \mathrm{~mm} /$ year) is higher than the mean value from the CMIP5 models $(586 \mathrm{~mm} /$ year).

There is a relatively good agreement between the CMIP5 models, CloudSat observations, and ERA Interim reanalysis for the snowfall rate over the coastal regions of the East Antarctic ice sheet (EAIS), with a mean snowfall rate in the CMIP5 models of $337 \mathrm{~mm} /$ year, compared to $283 \mathrm{~mm} /$ year in CloudSat observations and $259 \mathrm{~mm} /$ year in
ERA Interim reanalysis. However, the snowfall rate in the CMIP5 models ranges from 211 to $632 \mathrm{~mm} /$ year over this part of the ice sheet.

\subsection{Seasonal variability}

Figure 4 shows the seasonal variability of Antarctic precipitation simulated by the CMIP5 models and ERA Interim during the period 1986-2005, and observed with CloudSat during the period 2007-2010. On the Antarctic continent (north of $82^{\circ} \mathrm{S}$ ) and the peripheral areas, CloudSat data and ERA Interim indicate the same seasonality for Antarctic precipitation. The maximum snowfall rate is observed in March-April-May (MAM) followed by June-JulyAugust (JJA) and September-October-November (SON). The minimum snowfall rate is observed in the summer months of December-January-February (DJF). There are small differences in CloudSat data and ERA Interim reanalysis between the two seasons with the highest snowfall rate (MAM and JJA). 24 of the 40 CMIP5 models analyzed reproduce this seasonality on the continent north of $82^{\circ} \mathrm{S}$, and 26 of the 40 models capture the seasonality on the peripheral regions of the ice sheet.

Of the 13 models which reproduce a mean snowfall rate within $\pm 20 \%$ of CloudSat (Table 1), 7 models (ACCESS1-3, Bcc-csm1-1, CanESM2, CESM1-CAM5, FIO-ESM, HadGEM2-CC, and IPSL-CM5A-LR) produce the same seasonality as CloudSat and ERA Interim over the Antarctic continent (north of $82^{\circ} \mathrm{S}$ ). Overall, the models which reproduce relatively well the mean snowfall rate observed with CloudSat are not particularly better than the other models for simulating the seasonal variability of Antarctic snowfall.

In the interior of the ice sheet (surface elevation $>2250 \mathrm{~m}$ and north of $82^{\circ} \mathrm{S}$ ), where CloudSat observations are likely less reliable due to the relative contribution of
Fig. 4 Seasonal variability of the snowfall rate north of $82^{\circ} \mathrm{S}$ during the period 1986-2005 for the CMIP5 models and ERA Interim, and during the period 2007-2010 for CloudSat (\% compared to the mean annual snowfall rate). Red dots CloudSat, blue dots ERA Interim, and black dots CMIP5 climate models (Historical scenario)

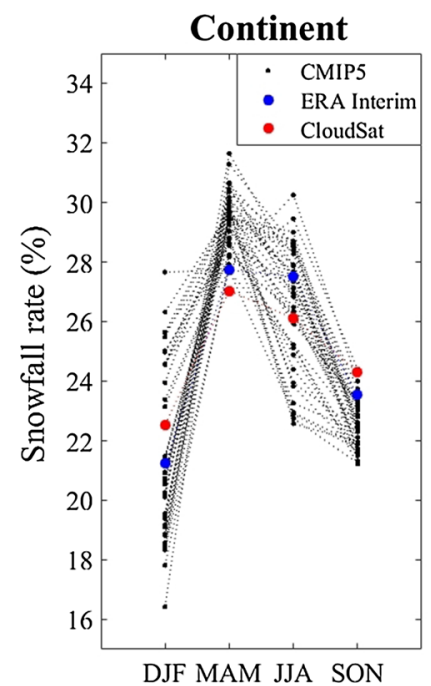

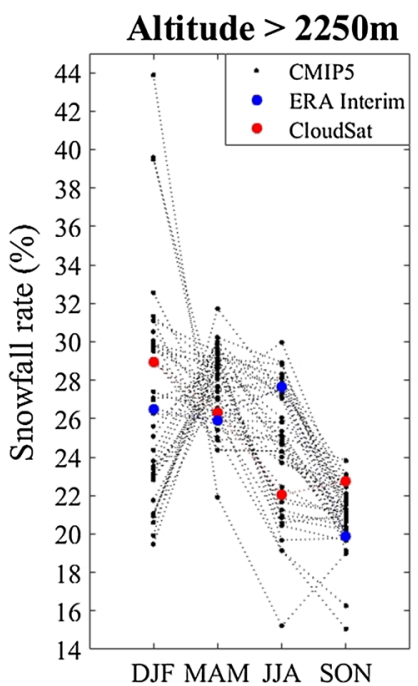


shallow precipitation, ERA Interim reanalysis disagree with the seasonal variability observed with CloudSat, especially during the winter months (JJA). The reason why CloudSat observations and ERA Interim reanalysis differ during the winter is not clear. The hydrometeors could be too small to be detected as snowfall particles in the CloudSat algorithm, or the contribution of shallow precipitation could be stronger during the winter. The reliability of ERA Interim to reproduce precipitation over the Antarctic plateau is not known, and could also be questionable. Furthermore, no clear seasonal variability can be extracted from the CMIP5 models archive in the interior of the ice sheet. There are more discrepancies between the CMIP5 models during the summer and the winter than during the fall and the spring.

\subsection{Trends in Antarctic precipitation during the period 1956-2005}

To study the trend in Antarctic precipitation simulated by the CMIP5 models, the total Antarctic precipitation rate (liquid + solid) has been averaged from the pole. During the last 50 years of the Historical scenario (1956-2005), all the CMIP5 models, except CMCC-CESM, produce a positive trend in Antarctic precipitation. The trend in Antarctic precipitation ranges from -0.6 to $5.5 \mathrm{~mm}$ per decade in the climate models, with a mean value of $2.3 \mathrm{~mm}$ per decade. On average, the CMIP5 models which reproduce a snowfall rate within $\pm 20 \%$ of the CloudSat snowfall rate produce a similar trend in Antarctic precipitation during the period 1956-2005 (2.1 mm per decade).

The trends in snow accumulation (defined as precipitation minus evaporation) are similar, ranging from -0.4 to $5.3 \mathrm{~mm}$ per decade, with a mean value of $1.9 \mathrm{~mm}$ per decade. The mean trend in Antarctic snow accumulation reproduced by the CMIP5 climate models is very close to the trend assessed by Monaghan et al. (2006) from ice cores and meteorological reanalysis $(1.9 \mathrm{~mm}$ per decade during the period 1955-2004), which is statistically insignificant. Furthermore, our results are in accordance with the findings of Monaghan et al. (2008), who reported a mean trend in snow accumulation of $1.7 \mathrm{~mm}$ per decade during the period 1955-1999 for a selection of five CMIP3 models.

\section{Model projections for the twenty-first century}

\subsection{Precipitation changes and consequences on sea level}

Future changes in Antarctic precipitation will impact the mass balance of the Antarctic ice sheet, and thus its contribution to sea level. That is why, the projections for the twenty-first century are calculated over the whole Antarctic continent (from the pole but excluding ice shelves). Furthermore, since most of the rain that falls in Antarctica refreezes in the snowpack due to low temperatures (Lenaerts et al. 2012), both forms of precipitation contribute to mass accumulation on the ice sheet. As a result, we consider total precipitation rate (liquid + solid) when assessing future changes in the RCP scenarios. However, liquid precipitation is rare and represents, on average, about $5 \%$ of the total Antarctic precipitation during the period 19862005 in the Historical scenario.

Table 1 provides the list of the models used for each RCP experiment. In this table, the models which simulate a snowfall rate during the period 1986-2005 in the Historical scenario within $20 \%$ of the CloudSat snowfall rate during the period 2007-2010, are written in italic and will be analyzed separately in this section.

Between the periods 1986-2005 and 2080-2099, precipitation changes varies from $-6.5 \%$ (GFDL-ESM2G) to $43.0 \%$ (CESM1-BGC) for the whole Antarctic continent depending on the models and the RCP scenarios (Table 2). On average, the Antarctic precipitation increase from the CMIP5 models varies from $5.5 \%$ for the scenario RCP2.6 to $24.5 \%$ for the scenario RCP8.5. If only the models which reproduce a snowfall rate close to the CloudSat observations are taken into account, this increase is,

Table 2 Relative precipitation changes (\%) in the CMIP5 models on the whole Antarctic continent (up to the pole), peripheral areas, and the interior of the ice sheet

\begin{tabular}{|c|c|c|c|c|}
\hline Scenario & Number of models & Mean & Minimum & Maximum \\
\hline \multicolumn{5}{|c|}{ Continent (up to the pole) } \\
\hline $\mathrm{RCP} 2.6$ & $29 / 10$ & $5.5 / 7.4$ & $-6.5 / 2.5$ & $15.5 / 13.3$ \\
\hline $\mathrm{RCP} 4.5$ & $39 / 13$ & $10.8 / 13.1$ & $-4.9 / 5.1$ & $21.9 / 21.9$ \\
\hline RCP6.0 & $20 / 7$ & $12.5 / 14.8$ & $-3.0 / 7.4$ & $26.2 / 26.2$ \\
\hline $\mathrm{RCP} 8.5$ & $38 / 13$ & $24.5 / 29.3$ & $1.8 / 17.9$ & $43.0 / 37.5$ \\
\hline \multicolumn{5}{|c|}{ Peripheral areas (surface elevation $<2250 \mathrm{~m}$ ) } \\
\hline $\mathrm{RCP} 2.6$ & $29 / 10$ & $5.1 / 6.9$ & $-6.2 / 2.3$ & $14.4 / 12.6$ \\
\hline $\mathrm{RCP} 4.5$ & $39 / 13$ & $10.0 / 12.2$ & $-4.7 / 4.5$ & $20.8 / 20.8$ \\
\hline RCP6.0 & $20 / 7$ & $11.4 / 13.5$ & $-2.8 / 6.6$ & $24.6 / 24.6$ \\
\hline $\mathrm{RCP} 8.5$ & $38 / 13$ & $22.6 / 27.0$ & $1.6 / 16.5$ & $39.5 / 32.8$ \\
\hline \multicolumn{5}{|c|}{ Interior of the ice sheet (surface elevation $>2250 \mathrm{~m}$ ) } \\
\hline $\mathrm{RCP} 2.6$ & $29 / 10$ & $7.8 / 9.6$ & $-7.8 / 3.4$ & $19.3 / 16.6$ \\
\hline $\mathrm{RCP} 4.5$ & $39 / 13$ & $14.5 / 16.9$ & $-6.2 / 7.8$ & $30.1 / 28.0$ \\
\hline RCP6.0 & $20 / 7$ & $17.6 / 20.4$ & $-4.0 / 11.4$ & $35.6 / 33.9$ \\
\hline RCP8.5 & $38 / 13$ & $33.1 / 39.6$ & $2.8 / 25.8$ & $59.0 / 56.8$ \\
\hline
\end{tabular}

The changes are calculated between the period 1986-2005 in the Historical scenario and the period 2080-2099 in the RCP scenarios. The relative precipitation changes for the models which simulate a snowfall rate close to the CloudSat snowfall rate $( \pm 20 \%)$ on the Antarctic continent north of $82^{\circ} \mathrm{S}$, during the period 1986-2005, are written in italic 


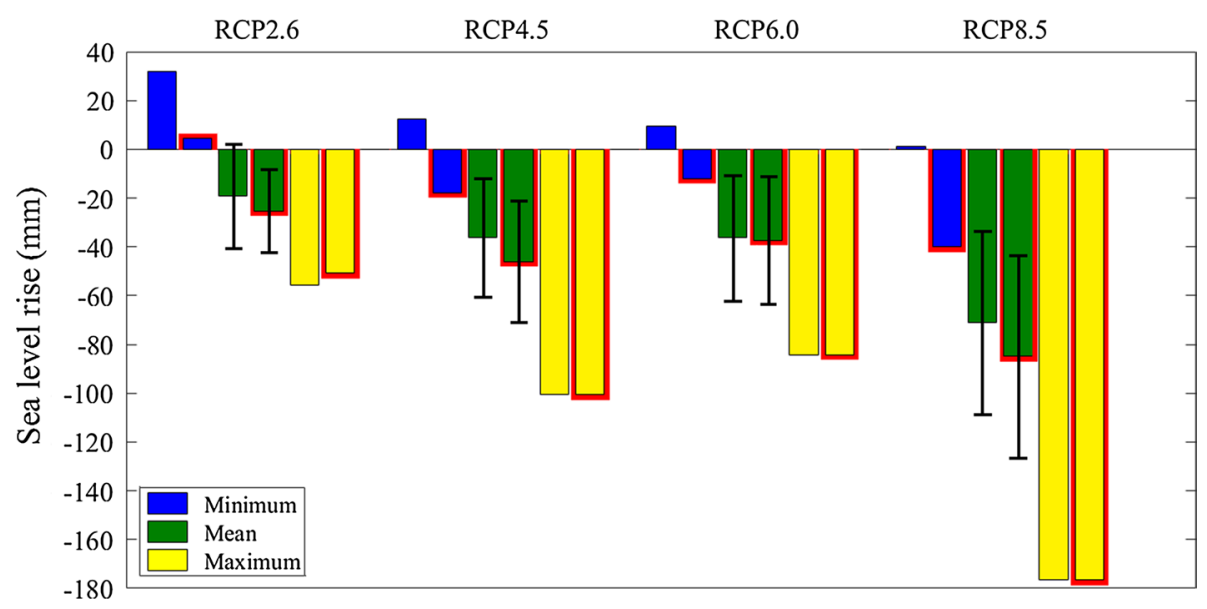

Fig. 5 Contribution of the Antarctic precipitation changes to sea level between 2006 and $2099(\mathrm{~mm})$ from the simulations of the CMIP5 models. The bars with the red contours show the contribution of the Antarctic precipitation changes to sea level from the models which simulate a snowfall rate during the period 1986-2005 close to the CloudSat snowfall rate $( \pm 20 \%)$ on the Antarctic continent (north of $82^{\circ} \mathrm{S}$ ). The error bars show the standard deviation of the contribution of the Antarctic precipitation changes to sea level simulated by the CMIP5 models
Fig. 6 Precipitation and annualmean near-surface air temperature (2 m) changes in Antarctica between the period 1986-2005 in the Historical scenario and the period 2080-2099 in the four RCP scenarios
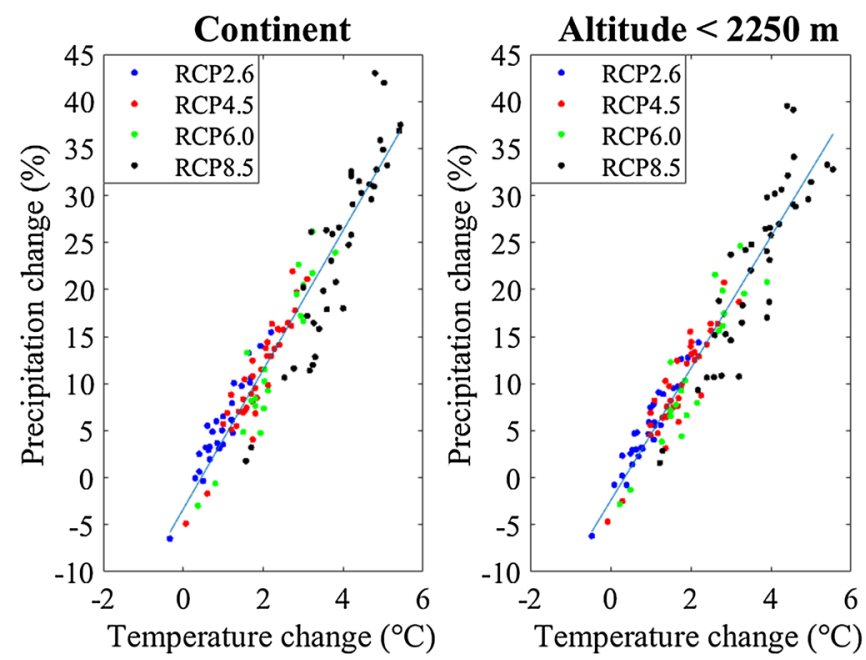

on average, larger in all the RCP experiments: from $7.4 \%$ for the scenario RCP2.6 to $29.3 \%$ for the scenario RCP8.5 (Table 2).

The relative increase of precipitation is larger in the interior of the ice sheet than on the peripheral areas (Table 2). However, the absolute increase from the CMIP5 models (not shown) is about three times larger on the peripheral areas (surface elevation $<2250 \mathrm{~m}$ ) than in the interior of the ice sheet (surface elevation $>2250 \mathrm{~m}$ ). Therefore, precipitation on the marginal regions of the ice sheet will contribute about three times more to the changes in total Antarctic precipitation than the precipitation on the Antarctic plateau since these two regions cover equal areas. This is in accordance with the findings of Genthon et al. (2009) who found the same result with the CMIP3 models.

From the evolution of Antarctic precipitation during the twenty-first century, it is possible to assess the contribution of Antarctic precipitation to sea level $[360 \mathrm{Gt}$ of ice is equivalent to $1 \mathrm{~mm}$ in sea level (Alley et al. 2005)]. On average from all the CMIP5 models, the contribution of Antarctic precipitation to sea level during the twenty-first century varies from $-19 \mathrm{~mm}$ for the scenario RCP2.6 to $-71 \mathrm{~mm}$ for the scenario RCP8.5 (Fig. 5). If only the models which reproduce a snowfall rate close to the CloudSat observations are taken into account, this contribution is larger: from $-25 \mathrm{~mm}$ for the scenario RCP2.6 to $-85 \mathrm{~mm}$ for the scenario RCP8.5. 


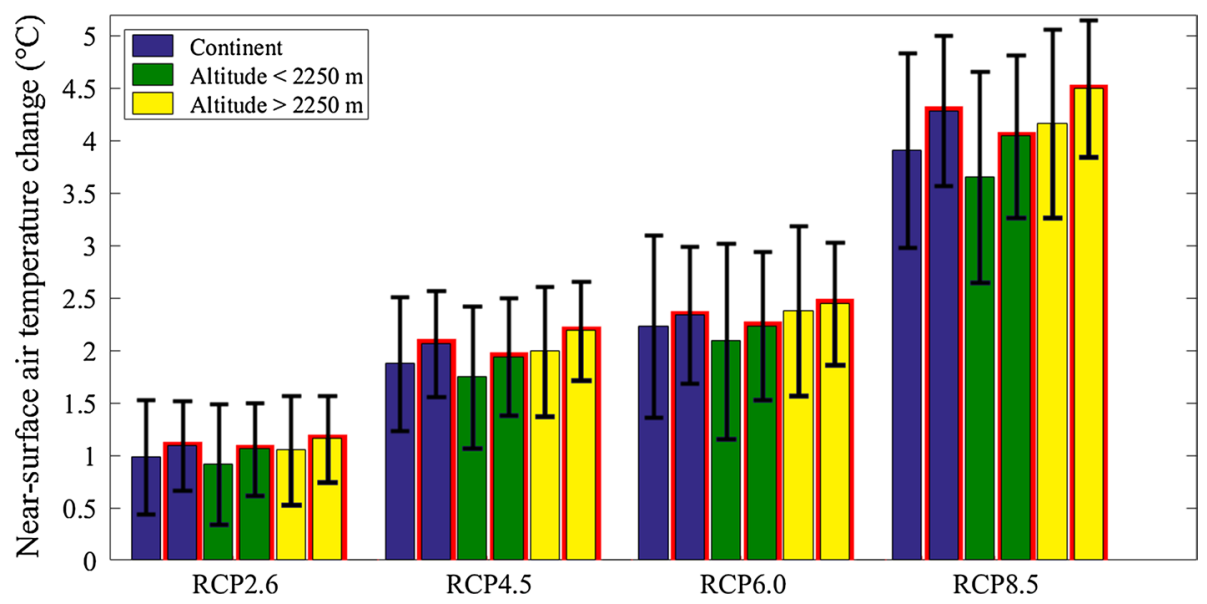

Fig. 7 Annual-mean near-surface air temperature $(2 \mathrm{~m})$ changes simulated by the CMIP5 models between the periods 1986-2005 in the Historical scenario and 2080-2099 in the four RCP scenarios. The bars with the red contours show the annual-mean near-surface air temperature $(2 \mathrm{~m})$ changes for the models which simulate a snowfall

\subsection{Precipitation and temperature changes}

If relative humidity remains constant with global warming, which is predicted by climate models (Held and Soden 2006), atmospheric water vapor content will increase with warmer temperatures (Clausius-Clapeyron relation). Due to this change in atmospheric water vapor content, Antarctic precipitation is also expected to increase during the twentyfirst century. The relative precipitation changes $\Delta P(\%)$ predicted by the CMIP5 models have been compared to the near-surface air temperature changes $\Delta T\left({ }^{\circ} \mathrm{C}\right)$ simulated by these models (Fig. 6). The correlation between these two variables is 0.95 for the whole Antarctic continent. A linear regression produces $\Delta P=7.4 \Delta T-3.3$ for the whole continent that can be partitioned as $\Delta P=7.0 \Delta T-2.5$ for the peripheral region and $\Delta P=9.3 \Delta T-4.0$ for the interior of the ice sheet.

Therefore, on the whole Antarctic continent, the sensitivity of precipitation changes to temperature variations is about $7.4 \% /{ }^{\circ} \mathrm{C}$. If only the climate models which reproduce a snowfall rate close to the CloudSat observations are taken into account, a similar sensitivity is obtained: $7.1 \% /{ }^{\circ} \mathrm{C}$. This sensitivity is at the high end of values reported in previous studies which range from $3 \% /{ }^{\circ} \mathrm{C}$ to about $7 \% /{ }^{\circ} \mathrm{C}$ (Gregory and Huybrechts 2006; Krinner et al. 2007; Bengtsson et al. 2011; Ligtenberg et al. 2013; Krinner et al. 2014). Furthermore, Frieler et al. (2015) have reported a sensitivity of snow accumulation to temperature of $6.1 \% /{ }^{\circ} \mathrm{C}$ using the CMIP5 models, and of $4.9 \% /{ }^{\circ} \mathrm{C}$ using the regional climate model RACMO2. Global precipitation is projected to increase by about $2 \% /{ }^{\circ} \mathrm{C}$ over rate during the period 1986-2005 close to the CloudSat snowfall rate $( \pm 20 \%)$ on the Antarctic continent (north of $82^{\circ} \mathrm{S}$ ). The error bars show the standard deviation of the near-surface air temperature $(2 \mathrm{~m})$ changes simulated by the CMIP5 models

the globe (Held and Soden 2006), thus this sensitivity is much larger in Antarctica, but it remains lower than the increase in atmospheric moisture capacity expected from the Clausius-Clapeyron relation which is about $9.7 \% /{ }^{\circ} \mathrm{C}$ at $-33{ }^{\circ} \mathrm{C}$ (the mean near-surface air temperature simulated by ERA Interim over the Antarctic continent during the period 1979-2012). However, in order to compare this sensitivity to the atmospheric moisture capacity changes, the temperature at the height of the precipitating clouds should be taken into account instead of the near-surface air temperature, which is used as a proxy here and in other studies (Gregory and Huybrechts 2006; Krinner et al. 2007; Bengtsson et al. 2011; Ligtenberg et al. 2013; Krinner et al. 2014).

The annual-mean near-surface air temperature changes predicted by the CMIP5 models are reported in Fig. 7. On average over the whole Antarctic continent, the models predict a temperature increase from $1.0{ }^{\circ} \mathrm{C}$ for the scenario $\mathrm{RCP} 2.6$ to $3.9^{\circ} \mathrm{C}$ for the scenario RCP8.5. These changes are stronger over the interior of the ice sheet than over the peripheral areas, which may explain why the relative precipitation increases are larger over the interior of the ice sheet. Over the whole Antarctic continent, the temperature increases simulated are larger in the models that closely reproduce the CloudSat snowfall rate than the full ensemble. These differences are small for the scenarios RCP2.6, RCP4.5, and RCP6.0, but approach $0.4{ }^{\circ} \mathrm{C}$ for the RCP8.5 scenario. Due to larger temperature increases simulated during the twenty-first century, the models considered as the most reliable for the current climate tend to predict larger changes in Antarctic precipitation. 
Fig. 8 Mean annual snowfall rate $(\mathrm{mm} /$ year) from the CMIP5 models over the whole Antarctic continent (from the pole) for the AMIP and the Historical scenarios during the period 1986-2005. The yellow bar shows the mean snowfall rate for all the CMIP5 models, and the green rectangle shows the standard deviation. Only the CMIP5 models with data available for the AMIP and the Historical scenarios have been taken into account

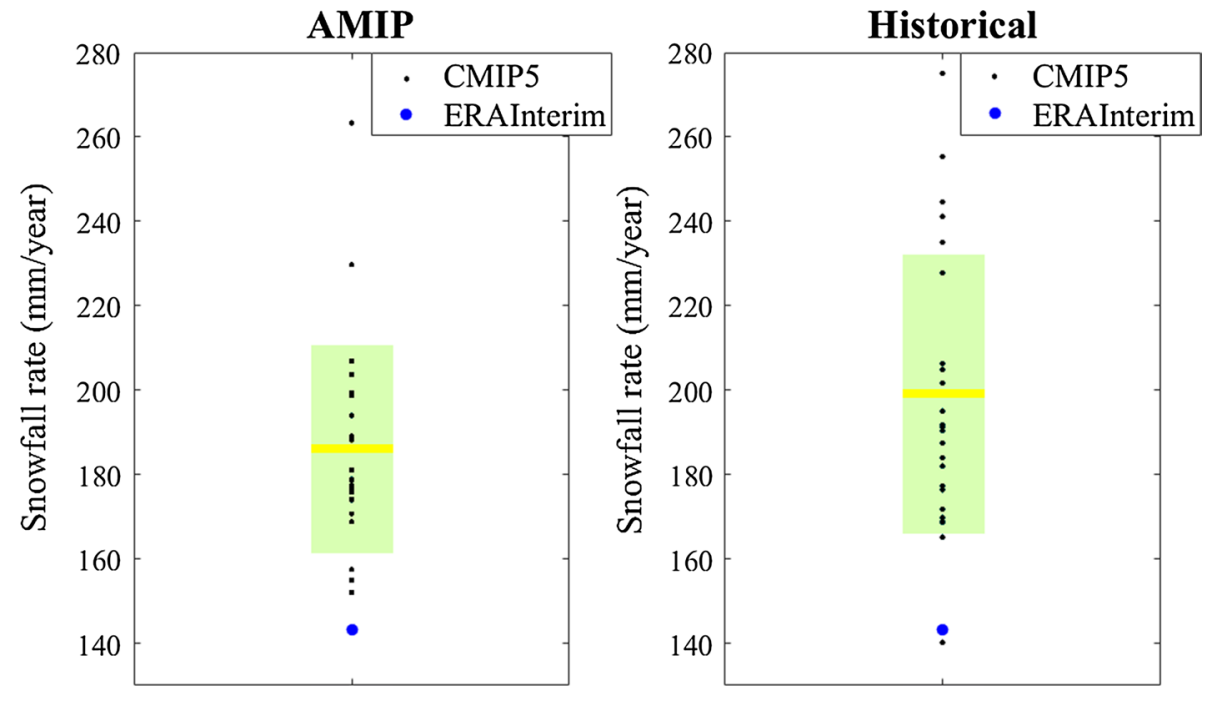

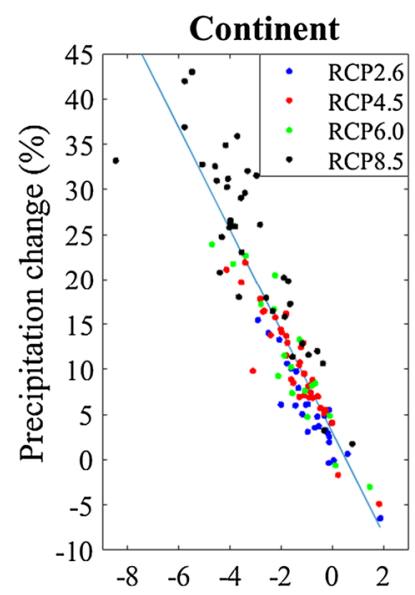
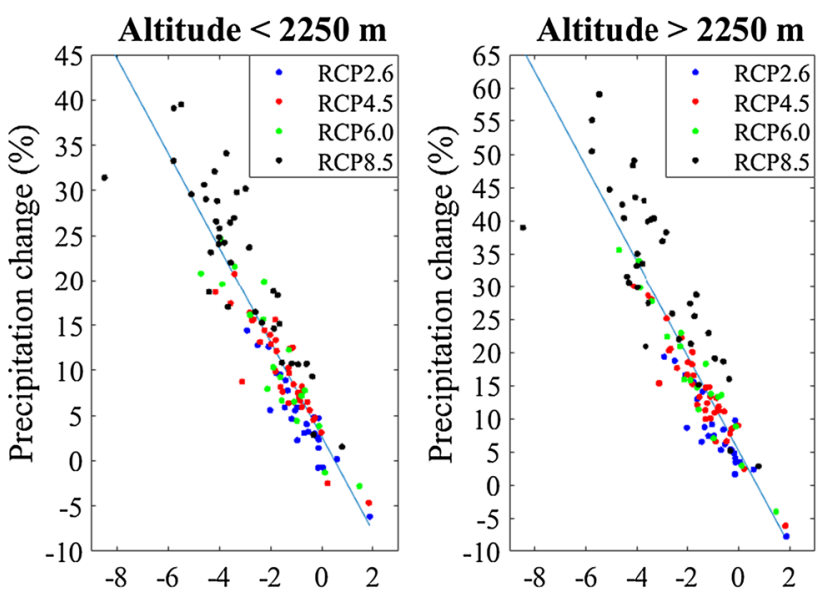

Sea ice area change $\left(10^{6} \mathrm{~km}^{2}\right)$ Sea ice area change $\left(10^{6} \mathrm{~km}^{2}\right)$ Sea ice area change $\left(10^{6} \mathrm{~km}^{2}\right)$

Fig. 9 Antarctic precipitation and annual-mean sea ice area in the southern hemisphere changes between the periods 1986-2005 in the Historical scenario and 2080-2099 in the four RCP scenarios

\subsection{Precipitation and sea ice cover changes}

Sea ice cover variations in the southern hemisphere are also expected to influence Antarctic precipitation through changes in moisture and energy exchanges between the ocean and the atmosphere. Nevertherless, changes in Antarctic near-surface air temperature and sea ice cover in the southern hemisphere are also well correlated (Krinner et al. 2014), and the relative influence of these two variables on Antarctic precipitation is difficult to assess.

The influence of sea surface conditions (sea ice and sea surface temperature) on Antarctic precipitation has been investigated in this study. The snowfall rate simulated by the CMIP5 models on the whole Antarctic continent (from the pole) in the Historical scenario and in the AMIP experiment have been compared in Fig. 8. Only the models with simulations available for the AMIP and the Historical scenarios have been taken into account ( 23 models). In the AMIP scenario, the atmospheric models are constrained by realistic sea surface conditions, while the coupled climate models are used in the Historical scenario. Therefore, contrary to the AMIP experiment, the simulations in the Historical scenario are subject to the ocean-atmosphere feedbacks. Figure 8 shows that there are more discrepancies for the mean snowfall rate between the models in the Historical scenario than in the AMIP scenario, thus the standard deviation of the snowfall rate is higher in the Historical scenario (33 mm/year compared to $24 \mathrm{~mm} /$ year for the AMIP scenario). Furthermore, the snowfall rate is, on average, higher in the Historical scenario (199 mm/year) than in the AMIP scenario (186 mm/year). Therefore, model biases in sea surface conditions affect precipitation in Antarctica. 


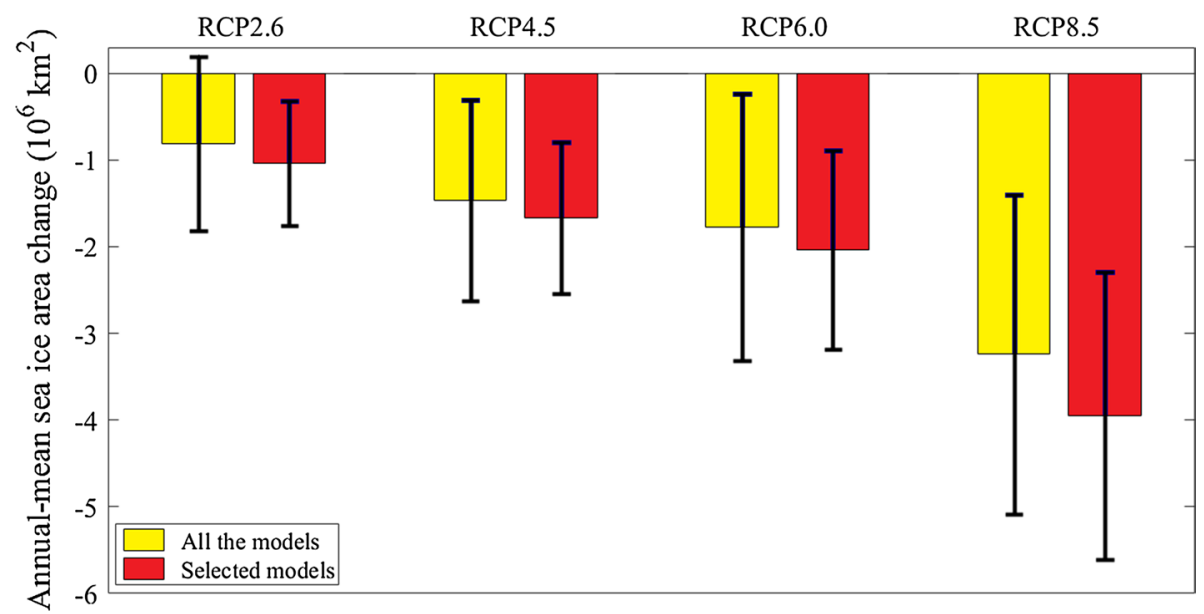

Fig. 10 Annual-mean sea ice area changes in the southern hemisphere simulated by the CMIP5 models between the periods 19862005 in the Historical scenario and 2080-2099 in the four RCP scenarios (yellow bars). The red bars show the annual-mean sea ice area changes for the models which simulate a snowfall rate during the

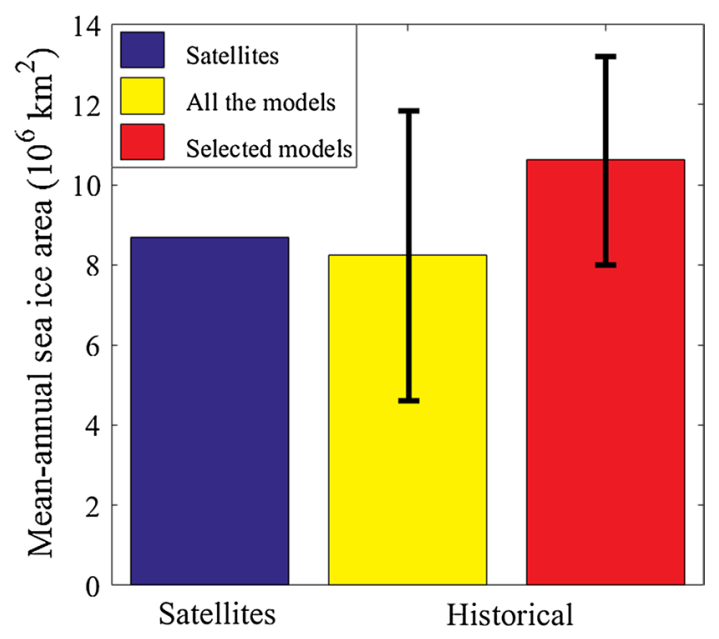

Fig. 11 Annual-mean sea ice area in the southern hemisphere simulated by the CMIP5 models during the period 1986-2005 in the Historical scenario (yellow bars). The red bars show the annual-mean sea ice area for the models which simulate a snowfall rate during the period 1986-2005 close to the CloudSat snowfall rate $( \pm 20 \%)$ on the Antarctic continent (north of $82^{\circ} \mathrm{S}$ ). The annual-mean sea ice area in the southern hemisphere observed by remote sensing during the period 1986-2005 has also been reported (blue bar). The error bars show the standard deviation of the sea ice area in the southern hemisphere simulated by the CMIP5 models

In this study, the sea ice area in the southern hemisphere has been analyzed (summed products of the grid cell areas times the ice concentrations for all grid cells). The annualmean sea ice area changes $\Delta S I\left(10^{6} \mathrm{~km}^{2}\right)$ predicted by the CMIP5 models have been compared to the relative precipitation changes $\Delta P(\%)$ simulated by these models (Fig. 9). The correlation between these two variables is -0.92 for period 1986-2005 close to the CloudSat snowfall rate $( \pm 20 \%)$ on the Antarctic continent (north of $82^{\circ} \mathrm{S}$ ). The error bars show the standard deviation of the sea ice area changes in the southern hemisphere simulated by the CMIP5 models

the whole Antarctic continent. A linear regression produces $\Delta P=-5.6 \Delta S I+3.1$ for the whole continent, $\Delta P=-7.1 \Delta S I+5.2$ for the interior of the ice sheet, and $\Delta P=-5.3 \Delta S I+2.7$ for the peripheral regions.

Figure 10 shows the annual-mean sea ice area changes in the southern hemisphere predicted by the CMIP5 models between the periods 1986-2005 and 2080-2099. On average, these changes vary from $-0.81 \times 10^{6} \mathrm{~km}^{2}$ for the scenario RCP2.6 to $-3.2 \times 10^{6} \mathrm{~km}^{2}$ for the scenario RCP8.5. Simulated sea ice area changes are stronger in the models that closely reproduce the CloudSat snowfall rate for the current period (Fig. 10). This suggests that the stronger Antarctic precipitation increases predicted by these models could be linked with larger sea ice area changes in the southern hemisphere simulated by these models.

The annual-mean sea ice areas simulated by the CMIP5 models during the period 1986-2005 have been reported in Fig. 11, and compared to sea ice area observations in the southern hemisphere provided by the U.S. National Snow and Ice Data Center (NSIDC). These observations have been obtained from data provided by the radiometers Scanning Multichannel Microwave Radiometer (SMMR), Special Sensor Microwave Imager (SSM/I), and Special Sensor Microwave Imager Sounder (SSMIS). Pixels with a sea ice concentration lower than $15 \%$ are screened from the analysis. Likewise, only model grid cells with a sea ice concentration higher than $15 \%$ are included.

On average, the sea ice area simulated by the CMIP5 models during the period 1986-2005 is smaller than the observed sea ice area by remote sensing (Fig. 11). However, the models that closely reproduce the CloudSat snowfall rate for the current period simulate, on average, 
a $22 \%$ larger sea ice area during the period 1986-2005 than observed (Fig. 11). Nevertherless, a few climate models (ACCESS1-0, HadGEM2-CC, IPSL-CM5A-LR, and NorESM1-M) reproduce relatively well Antarctic snowfall observed with CloudSat $( \pm 20 \%)$, and annual-mean sea ice area in the southern hemisphere observed by remote sensing $( \pm 20 \%)$.

\section{Discussion and conclusions}

Antarctic snowfall simulated by the CMIP5 climate models for the current period has been evaluated against the first model-independent climatology of Antarctic precipitation. For the Historical scenario, the mean snowfall rate (latitude $<82^{\circ} \mathrm{S}$ ) from the CMIP5 models during the period 19862005 ranges from 158 to $354 \mathrm{~mm} /$ year. Only 2 of the 40 climate models simulate a current snowfall rate lower than the rates from CloudSat observations and ERA Interim reanalysis.

In CloudSat observations and ERA Interim reanalysis, the maximum snowfall rate occurs in March-April-May and the minimum snowfall rate occurs in December-January-February. Most of the CMIP5 models produce a seasonal variability close to the CloudSat observations and ERA Interim reanalysis over the Antarctic continent (north of $82^{\circ} \mathrm{S}$ ). However, there is no agreement for the seasonality of Antarctic precipitation between CloudSat observations, ERA Interim reanalysis, and the CMIP5 models in the interior of the ice sheet, where the precipitation rates are very small.

The trend in Antarctic precipitation reproduced by the CMIP5 models during the period 1956-2005 is positive in all the models, except CMCC-CESM. On average, the trend in snow accumulation reproduced by the CMIP5 models ( $1.9 \mathrm{~mm}$ per decade) is very close to the trend assessed by Monaghan et al. (2006) from ice cores and meteorological reanalysis (1.9 $\mathrm{mm}$ per decade) during the period 1955 2004, which is not statistically significant.

Between the periods 1986-2005 and 2080-2099, the CMIP5 models predict, on average, a precipitation increase from $5.5 \%$ (scenario RCP2.6) to $24.5 \%$ (scenario RCP8.5). These changes in Antarctic precipitation correspond to a negative contribution to sea level between $-19 \mathrm{~mm}$ (scenario RCP2.6) and $-71 \mathrm{~mm}$ (scenario RCP8.5) between 2006 and 2099. About one third of the CMIP5 models reproduce a mean snowfall rate during the period 1986-2005 within $\pm 20 \%$ of the CloudSat observations. These models predict, on average, larger increases in Antarctic precipitation during the twenty-first century (from 7.4 to $29.3 \%$ for the scenarios RCP2.6 and RCP8.5 respectively), and thus larger global sea-level sinks associated with this process (from -25 to $-85 \mathrm{~mm}$ between
2006 and 2099 for the scenarios RCP2.6 and RCP8.5 respectively).

It is common practice to use the mean value from all the models for climate projections. However, if all the CMIP5 models are used to assess Antarctic precipitation changes, this leads to an underestimation of these changes, compared to the projections from the models best reproducing current Antarctic snowfall. This underestimation varies from $1.9 \%$ for the scenario RCP2.6 to $4.8 \%$ for the scenario RCP8.5 between the periods 1986-2005 and 2080-2099, which correspond to a difference in sea level from $6 \mathrm{~mm}$ (scenario RCP2.6) to $14 \mathrm{~mm}$ (scenario RCP8.5) between 2006 and 2099.

Most of the coastal stations have recorded increasing mean wind speeds in recent decades (Turner et al. 2005). Therefore ablation processes driven by katabatic winds should be taken into account to evaluate the future contribution of the Antarctic surface mass balance to sea level, particularly over the coastal areas of the ice sheet where the ablation caused by blowing snow is more important.

Agosta et al. (2015) have evaluated the ability of CMIP5 models to reproduce the Antarctic climate using five atmospheric and oceanic variables (sea level pressure, air temperature at $850 \mathrm{hPa}$, precipitable water, sea surface temperature, and sea ice extent). They suggested that ACCESS1-3 is the best CMIP5 model for modeling the Antarctic surface mass balance. The snowfall rate simulated by ACCESS1-3 between 1986 and 2005 is only about $16 \%$ larger than the one observed with CloudSat, confirming that ACCESS1-3 seems to be pertinent for modeling the Antarctic surface mass balance. ACCESS1-0, CESM1BGC, CESM1-CAM5, NorESM1-M, CCSM4, and ECEARTH have also been suggested as reliable models by Agosta et al. (2015). Among these models, ACCESS1-0, CESM1-CAM5, and NorESM1-M produce a snowfall rate within $\pm 20 \%$ of the snowfall rate observed with CloudSat. However, CESM1-BGC, CCSM4, and EC-EARTH simulate a snowfall rate during the period 1986-2005 less than $26 \%$ higher than the snowfall rate observed with CloudSat.

The results suggest that there is a connection between Antarctic precipitation, near-surface air temperature, and sea ice area in the southern hemisphere. The CMIP5 models predict, on average, an increase of Antarctic precipitation of $7.4 \% /{ }^{\circ} \mathrm{C}$. Furthermore, the models which closely reproduce Antarctic snowfall observed with CloudSat predict, on average, larger changes in near-surface air temperature and sea ice area in the southern hemisphere. This could be linked with the larger Antarctic precipitation increases predicted by these models during the twenty-first century. However, the relative impact of sea ice cover and temperature changes on Antarctic precipitation is difficult to assess and is beyond the scope of this study. 
Future spaceborne radar missions, such as the EarthCARE satellite scheduled for launch in 2017 (Kumagai et al. 2003), should provide new observations for evaluating Antarctic precipitation in the climate models. Furthermore, field observations are sparse and rare in Antarctica, which prevents a robust evaluation of remote sensing retrievals. For instance, determining the contribution of shallow precipitation to total precipitation remains an issue, and in-situ observations, as those presented by Gorodetskaya et al. (2015), should provide new informations for assessing the contribution of shallow precipitation. New in-situ observations of precipitation are needed in Antarctica to evaluate and improve remote sensing retrievals, and thus for more robust evaluation of climate model simulations.

Acknowledgements This study was supported by the LEFE programmes CLAPA and DEPHY2 (Institut National des Sciences de l'Univers), and by the French National Research Agency (ANR) through the APRES3 project, ANR-15-CE01-0003. Support from the European Community Unions Framework Programme under grant agreement number 603608 (Earth2Observe project) is gratefully acknowledged. We are grateful to the Centre National d'Études Spatiales (CNES). Funding for this project was provided by a grant from la Région Rhône-Alpes. J.E.K. was funded by NASA grant 12-CCST10-0095. Parts of this research conducted by N. B. Wood and T. LEcuyer were performed at the University of Wisconsin- Madison for the Jet Propulsion Laboratory, California Institute of Technology, sponsored by National Aeronautics and Space Administration CloudSat Research Grant G-3969-1. Finally, we thank the four anonymous reviewers for their comments which significantly improved the manuscript.

Open Access This article is distributed under the terms of the Creative Commons Attribution 4.0 International License (http://creativecommons.org/licenses/by/4.0/), which permits unrestricted use, distribution, and reproduction in any medium, provided you give appropriate credit to the original author(s) and the source, provide a link to the Creative Commons license, and indicate if changes were made.

\section{References}

Agosta C, Fettweis X, Datta R (2015) Evaluation of the CMIP5 models in the aim of regional modelling of the Antarctic surface mass balance. Cryosphere 9:2311-2321. doi:10.5194/tc-9-2311-2015

Alley RB, Clark PU, Huybrechts P, Joughin I (2005) Ice-sheet and sea-level changes. Science 310:456-460. doi:10.1126/ science. 1114613

Arthern RJ, Winebrenner DP, Vaughan DG (2006) Antarctic snow accumulation mapped using polarization of $4.3-\mathrm{cm}$ wavelength microwave emission. J Geophys Res: Atmos. doi:10.1029/200 4JD005667

Bengtsson L, Koumoutsaris S, Hodges K (2011) Large-scale surface mass balance of ice sheets from a comprehensive atmospheric model. Surv Geophys 32:459-474. doi:10.1007/ s10712-011-9120-8

Bindschadler R, Choi H, Shuman C, Markus T (2005) Detecting and measuring new snow accumulation on ice sheets by satellite remote sensing. Remote Sens Environ 98:388-402. doi:10.1016/j.rse.2005.07.014
Bromwich DH (1988) Snowfall in high southern latitudes. Rev Geophys 26:149-168. doi:10.1029/RG026i001p00149

Bromwich DH, Guo Z, Bai L, Qs Chen (2004) Modeled Antarctic precipitation. part i: spatial and temporal variability. J Climate 17:427-447

Bromwich DH, Nicolas JP, Monaghan AJ (2011) An assessment of precipitation changes over Antarctica and the southern ocean since 1989 in contemporary global reanalyses. J Climate 24:4189-4209. doi:10.1175/2011JCLI4074.1

Church JA, Clark PU, Cazenave A, Gregory JM, Jevrejeva S, Levermann A, Merrifield MA, Milne GA, Nerem RS, Nunn PD, Payne AJ, Pfeffer WT, Stammer D, Unnikrishnan AS (2013) Sea level change. In: Stocker TF, Qin D, Plattner GK, Tignor M, Allen SK, Boschung J, Nauels A, Xia Y, Bex V, Midgley PM (eds) Climate change 2013: the physical science basis. Contribution of working group I to the fifth assessment report of the intergovernmental panel on climate change, Cambridge University Press, Cambridge and New York

Dee DP, Uppala SM, Simmons AJ, Berrisford P, Poli P, Kobayashi S, Andrae U, Balmaseda MA, Balsamo G, Bauer P, Bechtold P, Beljaars ACM, van de Berg L, Bidlot J, Bormann N, Delsol C, Dragani R, Fuentes M, Geer AJ, Haimberger L, Healy SB, Hersbach H, Hlm EV, Isaksen L, Kllberg P, Khler M, Matricardi M, McNally AP, Monge-Sanz BM, Morcrette JJ, Park BK, Peubey C, de Rosnay P, Tavolato C, Thpaut JN, Vitart F (2011) The era-interim reanalysis: configuration and performance of the data assimilation system. Quart J R Meteorol Soc 137:553-597. doi:10.1002/qj.828

Frezzotti M, Scarchilli C, Becagli S, Proposito M, Urbini S (2013) A synthesis of the Antarctic surface mass balance during the last 800 year. Cryosphere 7:303-319. doi:10.5194/tc-7-303-2013

Frieler K, Clark PU, He F, Buizert C, Reese R, Ligtenberg SRM, van den Broeke MR, Winkelmann R, Levermann A (2015) Consistent evidence of increasing Antarctic accumulation with warming. Nat Clim Change 5:348-352

Fujita K, Abe O (2006) Stable isotopes in daily precipitation at dome fuji, east Antarctica. Geophys Res Lett. doi:10.1029/200 6GL026936

Gates WL (1992) Amip: the atmospheric model intercomparison project. Bull Am Meteorol Soc 73(12):1962-1970

Genthon C, Krinner G, Castebrunet H (2009) Antarctic precipitation and climate change predictions: horizontal resolution and margin vs plateau issues. Ann Glaciol 50:55-60

Gorodetskaya IV, Kneifel S, Maahn M, Van Tricht K, Thiery W, Schween JH, Mangold A, Crewell S, Van Lipzig NPM (2015) Cloud and precipitation properties from ground-based remotesensing instruments in east Antarctica. Cryosphere 9:285-304. doi:10.5194/tc-9-285-2015

Gregory J, Huybrechts P (2006) Ice-sheet contributions to future sea-level change. Philos Trans R Soc A: Math Phys Eng Sci 364:1709-1732. doi:10.1098/rsta.2006.1796

Held IM, Soden BJ (2006) Robust responses of the hydrological cycle to global warming. J Climate 19:5686-5699. doi:10.1175/ JCLI3990.1

Krinner G, Magand O, Simmonds I, Genthon C, Dufresne JL (2007) Simulated Antarctic precipitation and surface mass balance at the end of the twentieth and twenty-first centuries. Climate Dyn 28:215-230. doi:10.1007/s00382-006-0177-x

Krinner G, Largeron C, Mngoz M, Agosta C, Brutel-Vuilmet C (2014) Oceanic forcing of Antarctic climate change: a study using a stretched-grid atmospheric general circulation model. J Climate 27:5786-5800. doi:10.1175/JCLI-D-13-00367.1

Kumagai H, Kuroiwa H, Kobayashi S, Orikasa T (2003) Cloud profiling radar for earthcare mission. Proc SPIE 4894:118-125

Lenaerts JTM, van den Broeke MR, van de Berg WJ, van Meijgaard E, Kuipers Munneke P (2012) A new, high-resolution surface mass balance map of Antarctica (1979-2010) based on regional 
atmospheric climate modeling. Geophys Res Lett. doi:10.1029/2 011GL050713

Ligtenberg S, van de Berg W, van den Broeke M, Rae J, van Meijgaard E (2013) Future surface mass balance of the Antarctic ice sheet and its influence on sea level change, simulated by a regional atmospheric climate model. Climate Dyn 41:867-884. doi:10.1007/s00382-013-1749-1

Liu G (2008) Deriving snow cloud characteristics from cloudsat observations. J Geophys Res: Atmos. doi:10.1029/200 7JD009766

Magand O, Genthon C, Fily M, Krinner G, Picard G, Frezzotti M, Ekaykin AA (2007) An up-to-date quality-controlled surface mass balance data set for the 90180e Antarctica sector and 19502005 period. J Geophys Res: Atmos. doi:10.1029/200 6JD007691

Magand O, Picard G, Brucker L, Fily M, Genthon C (2008) Snow melting bias in microwave mapping of Antarctic snow accumulation. Cryosphere 2:109-115. doi:10.5194/tc-2-109-2008

Medley B, Joughin I, Das SB, Steig EJ, Conway H, Gogineni S, Criscitiello AS, McConnell JR, Smith BE, van den Broeke MR, Lenaerts JTM, Bromwich DH, Nicolas JP (2013) Airborne-radar and ice-core observations of annual snow accumulation over Thwaites glacier, West Antarctica confirm the spatiotemporal variability of global and regional atmospheric models. Geophys Res Lett 40(14):3649-3654. doi:10.1002/grl.50706

Monaghan AJ, Bromwich DH, Fogt RL, Wang SH, Mayewski PA, Dixon DA, Ekaykin A, Frezzotti M, Goodwin I, Isaksson E, Kaspari SD, Morgan VI, Oerter H, Van Ommen TD, Van der Veen CJ, Wen J (2006) Insignificant change in Antarctic snowfall since the international geophysical year. Science 313:827-831. doi:10.1126/science. 1128243

Monaghan AJ, Bromwich DH, Schneider DP (2008) Twentieth century Antarctic air temperature and snowfall simulations by ipcc climate models. Geophys Res Lett. doi:10.1029/2007GL032630 107502

Moss RH, Edmonds JA, Hibbard KA, Manning MR, Rose SK, van Vuuren DP, Carter TR, Emori S, Kainuma M, Kram T, Meehl GA, Mitchell JFB, Nakicenovic N, Riahi K, Smith SJ, Stouffer RJ, Thomson AM, Weyant JP, Wilbanks TJ (2010) The next generation of scenarios for climate change research and assessment. Nature 463:747-756. doi:10.1038/nature08823

Palerme C, Kay JE, Genthon C, L'Ecuyer T, Wood NB, Claud C (2014) How much snow falls on the Antarctic ice sheet? Cryosphere 8:1577-1587. doi:10.5194/tc-8-1577-2014
Rignot E, Bamber JL, van den Broeke MR, Davis C, Li Y, van de Berg WJ, van Meijgaard E (2008) Recent Antarctic ice mass loss from radar interferometry and regional climate modelling. Nat Geosci 1:106-110. doi:10.1038/ngeo102

Shepherd A, Ivins ER, Geruo A, Barletta VR, Bentley MJ, Bettadpur S, Briggs KH, Bromwich DH, Forsberg R, Galin N, Horwath M, Jacobs S, Joughin I, King MA, Lenaerts JTM, Li J, Ligtenberg SRM, Luckman A, Luthcke SB, McMillan M, Meister R, Milne G, Mouginot J, Muir A, Nicolas JP, Paden J, Payne AJ, Pritchard H, Rignot E, Rott H, Srensen LS, Scambos TA, Scheuchl B, Schrama EJO, Smith B, Sundal AV, van Angelen JH, van de Berg WJ, van den Broeke MR, Vaughan DG, Velicogna I, Wahr J, Whitehouse PL, Wingham DJ, Yi D, Young D, Zwally HJ (2012) A reconciled estimate of ice-sheet mass balance. Science 338:1183-1189. doi:10.1126/science.1228102

Simmons A, Uppala S, Dee D, Kobayashi S (2006) Era-interim: new ecmwf re-analysis products from 1989 onwards. ECMWF Newslett 110:2535

Stephens GL, Vane DG, Tanelli S, Im E, Durden S, Rokey M, Reinke D, Partain P, Mace GG, Austin R, L'Ecuyer T, Haynes J, Lebsock M, Suzuki K, Waliser D, Wu D, Kay J, Gettelman A, Wang Z, Marchand R (2008) Cloudsat mission: Performance and early science after the first year of operation. J Geophys Res: Atmos. doi:10.1029/2008JD009982

Taylor KE, Stouffer RJ, Meehl GA (2012) An overview of CMIP5 and the experiment design. Bull Amer Meteor Soc 93:485-498. doi:10.1175/BAMS-D-11-00094.1

Turner J, Colwell SR, Marshall GJ, Lachlan-Cope TA, Carleton AM, Jones PD, Lagun V, Reid PA, Iagovkina S (2005) Antarctic climate change during the last 50 years. Int J Climatol 25:279-294. doi:10.1002/joc. 1130

Vaughan DG, Bamber JL, Giovinetto M, Russell J, Cooper APR (1999) Reassessment of net surface mass balance in Antarctica. J Climate 12:933-946

Velicogna I (2009) Increasing rates of ice mass loss from the greenland and Antarctic ice sheets revealed by grace. Geophys Res Lett. doi: 10.1029/2009GL040222

Wood NB, L'Ecuyer T, Vane DG, Stephens GL, Partain P (2013) Level 2C Snow Profile process description and interface control document, version 0. http://www.cloudsat.cira.colostate. edu/sites/default/files/products/files/2C-SNOW-PROFILE_ PDICD.P_R04.20130210.pdf. Accessed 22 Mar 2016 